\title{
A Conceptual Architectural Design Process For Ventilation in Built Environment
}

\author{
Yapma Çevrede Havalandırmaya Yönelik Kuramsal Bir Mimari Tasarım Yaklaşımı
}

\author{
Polat DARÇIN
}

ABSTRACT

Built environments affect other environments according to their properties and relations. Wrong / inadequate decisions in design stage may cause many adverse effects. One of the important aspects of built environments is air related properties. In the light of regenerative design, which sees built environment as a new and organized bridge effectuating the desired relationship between different nested systems of place, a strategic guidance is determined as a basic necessity in order to design buildings with accurate ventilation and air properties. Concerning ventilation in buildings to be effective, it is important for clean air to reach settlements and polluted air should be removed through the relation and coherence of air and its movement with the properties of built environment in different scales. This aim can be met by using a design approach based on patterns, relations and impacts; a decision making tool of this kind can also be beneficial for evaluation of existing built environments in terms of air and ventilation efficiency. The proposed approach starts with a pre-research phase of collecting many data about the design area, continues with design / analysis phase in which certain design decisions are made based on the findings of pre-research or examination of existing building. The last phase is evaluating the design in terms of quality of meeting air related requirements and providing feedbacks. Designing this kind of built environment can integrate humans and other systems of design area to generate some net positive and supportive results.

Keywords: Air quality; architectural design; built environment; systems thinking; ventilation.

ÖZ

Yapma çevreler, özellikleri ve ilişkileri doğrultusunda diğer çevreleri etkilemektedir. Bu çevrelerin tasarlanması sırasında alınmış yanlışya da eksik kararlar birçok olumsuzluğa neden olabilir. Söz konusu önemli özelliklerden birisi yapma çevredeki havanın niteliğidir. Yere ilişkin farklı özellikte ve iç içe geçmiş sistemler arasında oluşturulması arzulanan ilişkileri kurgulayabilecek bir yapma çevre öngörüsü güden yenileyici tasarım yaklaşımının ilkeleri doğrultusunda, doğru ve yeterli bir şekilde havalandırılan ve hava niteliğinin olumlu olduğu yapma çevrelerin tasarlanabilmesi için bir yöntem geliştirilmiştir. Havalandırmanın etkili olabilmesi için temiz havanın yerleşimlere ve yapıya ulaşması, kirlenen havanın ise uzaklaştırılması gerekir. Bu durum, havanın ve hava deviniminin, yapma çevrenin farklı ölçeklerdeki özellikleriyle ilişkisi ve uyumuyla sağlanabilir. Belirtilen amaca ulaşmak için yerde var olan örgülere, ilişkilere ve etkilere dayalı bir tasarım yordamının gerekli olduğu, bu tür bir karar verme aracının aynı zamanda var olan yapma çevrelerdeki hava ve havalandırma niteliğinin bu çevrelerin mimari tasarım özellikleri üzerinden irdelenmesine de yarar sağlayacağı düşünülmektedir. Önerilen yaklaşım bağlama ilişkin birçok verinin toplandığı bir ön araştırma aşaması ile başlamakta ve ön araştırmada elde edilen verilere dayanarak belirli tasarım kararlarının oluşturulduğu tasarım / analiz aşaması ile devam etmektedir. Yaklaşımın son aşaması ise tasarımın hava ile ilgili gereksinmeleri karşılaması açısından değerlendirildiği ve bir önceki aşamaya yönelik geri beslemelerin oluşturulduğu bölümdür. Bu tür bir yöntemin kullanılmasıyla, insanları ve yerdeki diğer sistemleri karşılıklı yarar sağlayacak şekilde ilişkilendirecek ve net pozitif sonuçlar doğuracak bir yapma çevrenin oluşturulabileceği varsayılmaktadır.

Anahtar sözcükler: Hava niteliği; mimari tasarım; yapma çevre; sistem organizasyonu; havalandırma.

Department of Architecture, Yıldız Technical University Faculty of Architecture, Istanbul, Turkey

Article arrival date: June 18, 2018 - Accepted for publication: January 10, 2020

Correspondence: Polat DARÇIN. e-mail: darcinpolat@yahoo.com

๑ 2020 Yıldız Teknik Üniversitesi Mimarlık Fakültesi - ๑ 2020 Yıldız Technical University, Faculty of Architecture 


\section{Introduction}

It is a well known fact that humans and societies, forging their endeavors within the overarching value frame of prevailing paradigms, can harm nature (Rees, 1999) - especially during the construction, usage and after-use stages of built environments. Either a small scale building or a city, built environments affect natural and social environments according to the decisions about their different aspects. One of these aspects is the properties of air to meet one of the main requirements of users: access to clean and comfortable air.

Buildings can be ventilated and air can be conditioned by using mechanical systems and / or with natural / passive methods. In spite of many advantageous aspects of both choices, wrong / inadequate decisions about air during design stage, environmental pollution can increase in consequence of energy depletion from non-renewable sources, indoor air pollution with serious health (Balanlı ve Öztürk, 1995) and economical (CEC, 1991) outcomes may occur. Moreover, some restrictions may come up due to incompatible environmental factors.

Adverse effects of built environment harm its users and prevent perpetuation of natural environment in a healthy situation. Rees (2008) discusses that negative impacts even reduced - of human endeavors consequently lead to depletion of nature. Similarly, du Plessis (2012) says an evolutionary "dead end" is being encountered as the result of intersection between current methods and natural boundaries. These statements conceived a need for a transformation in thinking systems (Haggard, Reed, Mang, 2008) as well as decision making processes.

Regenerative paradigm, emerged in this conjuncture, basically aims to constitute a relationship between humans and nature in the frame of co-equal partnership (Cole, 2012) and targets to be mutually beneficial (Pedersen Zari, 2012). The projection of this paradigm on the built environment, regenerative design, is an approach that sees the built environment as a new and organized ecosystem to serve to effectuate the desired relationship and wants to benefit from and simultaneously be useful to bigger and smaller nested systems of design area through built environment (Darçın, 2014a). These aims can be managed with serious alterations for processes of different aspects of built environment, as well as air related decisions.

Although there is a wide range of studies about different aspects of ventilation in scientific literature, it is believed that there is a need for a systematic approach in order to relate all these aspects into a strategic guidance for those intending to design buildings with accurate ventilation and air properties. Also, many building performance assessment methods can be determined to inspect and evaluate the design of a building according to some specific objectives focusing only on individual building scale which cause discussions and suspicions about their evaluation results (Darçın, Tuna Taygun, Vural, 2016). In order to overcome these problems, a shift of focus should be executed from individual building performance to a focus on underlying patterns, relations and integrations between aspects and impacts of air, its quality and movement across different spatial scales through its compatibility to regional characteristics.

The aim of this research is to constitute an integrated and interdependent design process approach for ventilation and air conditioning in a building as a decision making tool in scope of systems thinking. It is estimated that with the assistance of this kind of approach, finding tangible solutions about air properties through architectural design, that originate from and are supported by other systems of the place, can be facilitated for transition to net positive built environments.

This paper focuses on the relationship of built and natural environments in terms of air properties; the subject is limited with theoretical relation of aspects in a strategic approach in the light of regenerative design principles. Proposed approach can be advantageous for organization of a quantification process about air related performance which otherwise can be time - labor - money consuming. The study basically has two main parts:

- examination of air, its movement and various effects that change its properties,

- proposal of architectural design approach for accurate air properties in and around a building.

\section{The Properties of Air and Its Movement}

The air of the atmosphere is a mixture of $78,1 \%$ nitrogen, $20,94 \%$ oxygen, $0,09 \%$ argon and small amounts of other gasses and water vapor (Spellman, 2009).

For the movement of air, there must be a natural or human induced pressure differentiation. Naturally, it is related to air temperature. The air, gaining heat, dilates, rises with the decrease in its pressure and is replaced by cold air. Due to this fact, the air always moves from high (positive) pressure zone to low (negative) pressure zone at a certain speed (Fig. 1a). The speed, direction (Fig. 1b), behavior (Fig. 1c, d) and form (Fig. 1d) of the flow may change according to properties of obstacles on its path. High or low pressure zones can be created (Fig. 1d-f) around an obstacle by the flow.

Any changes in normal percentage of the gases or accumulation of harmful substances in the air are defined as air pollution. Different types of pollutants can be transported by air movements and can affect humans adversely if they are exposed to certain concentrations for a defined period of time. 


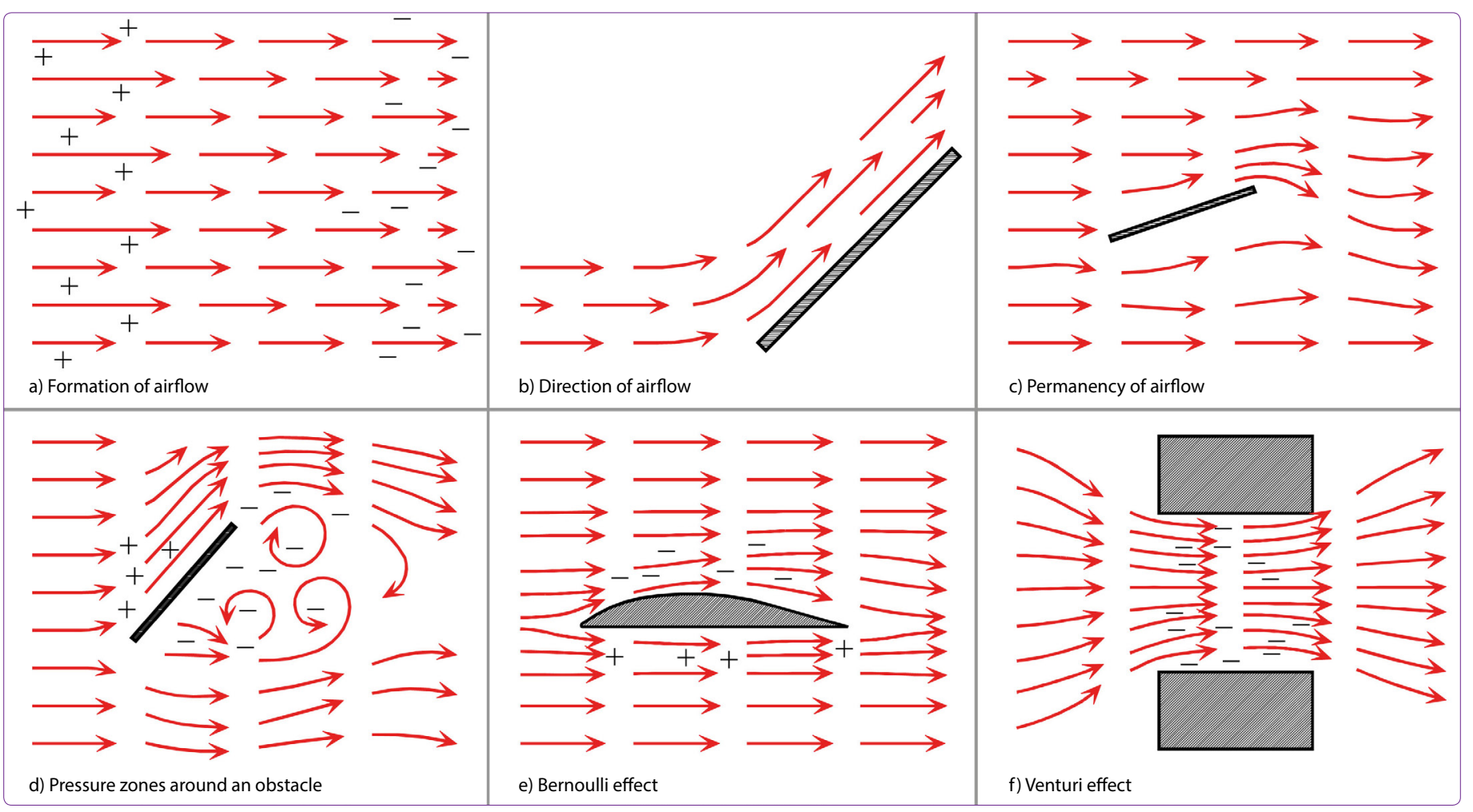

Figure 1. The formation, direction and behavior of airflow (adapted from Yaşa, 2004).

Concerning ventilation in buildings to be sufficient and effective, it is necessary that clean air can reach settlements and buildings and constantly polluted air should be removed. Therefore, the relation and coherence of air and its movement with the properties of built environment have an essential role over air quality.

The building can be defined as an object due to separating a part of nature and transforming this space into units inside an envelope and as a built environment for enclosing indoor and being encircled with outdoor environments (Balanlı, 2011). Outdoor environment, which may contain natural and built environments, is constantly and mutually interacting with indoor environment. This relationship is mainly defined and affected by the envelope of the building. Many properties of outdoor and indoor environments can affect the quality of air and the formation and properties (speed, direction, behavior and form) of airflow.

\section{The Effects of Outdoor Environment on Air}

The main factor on the formation of airflow is the sun. Air pressure differentiations and thereby air movements can occur due to different heat gains of atmosphere and components of natural and built environments from sun rays in macro and micro scales. The properties of airflow are related to positions of different pressure zones, difference between pressure levels and effects of outdoor environment components as obstacles on the path.
Air of outdoor environment is constantly polluted by different sources. Pollutants can emanate from natural and built environments. The properties of pollution depend on the type and quantity of pollutants which are basically contingent on their sources. The main sources in the outdoor environment can be grouped as human activities, building and other industrial products, earth, water and living entities (Table 1) (Darçın, 2014b). For the health of humans and other living entities, it is essential that the air pollutants should be reduced to a level in which the life cycle of these pollutants can be completed by natural processes without causing any harm. One of the proper ways of this reduction is the transportation of pollutants away from the outdoor environment of buildings via air movements.

The formation and properties of air movements in the settlements and around the buildings are affected by the components of natural and built environments. As seen in Table 2, the relationship of sun with different components of natural and built environments may form air movements in different scales, whereas Table 3 shows that same components may act as obstacles on the path of airflow and change its properties.

Appropriate clean air can reach buildings and polluted air can be removed, if the stated components of outdoor environment are arranged in a form that contributes to the formation and are compatible with movement norms of airflow (Darçın, Balanlı, 2010). 
Table 1. Main pollutant resources in outdoor environment

\begin{tabular}{|c|c|c|}
\hline Pollutant resources & & Emitted pollutants \\
\hline Human activities & Combustion for heating, cooking, etc. & Smoke from organic fuels \\
\hline & Fire & Smoke from industrial products \\
\hline & Industrial production & Various pollutants \\
\hline & Using motor vehicles & $\begin{array}{l}\text { Smoke containing CO (Flachsbart, 2007), PM0, } 1 \text { (Jantunen, 2000), } \\
\text { some VOCs (Wallace, Gordon, 2007), asbestos (Balanlı, Tuna Taygun, } \\
\text { 2005), etc. }\end{array}$ \\
\hline & Pest control & Pesticides \\
\hline $\begin{array}{l}\text { Building and other } \\
\text { industrial products }\end{array}$ & & Many pollutants such as asbestos, lead, etc. \\
\hline Earth and rocks & & $\begin{array}{l}\text { Radon (Balanlı, Vural, Tuna Taygun, 2004), lead (EPA, 1994), PM } \\
\text { (Jantunen, 2000), etc. }\end{array}$ \\
\hline Water & & PM (Bérubé, Richards, 2000), VOCs (EEA, 2013), etc. \\
\hline Living entities & Plants & Pollen (Muilenberg, 2001), VOCs (EEA, 2013), etc. \\
\hline & Animals and insects & PM \\
\hline & Mold & Mold spores (EPA, 2001) \\
\hline
\end{tabular}

\section{Effects of Building on Air}

Buildings, which consist of a permeable envelope through air intake / outlet areas such as wall openings (windows, doors, etc.); turrets, shafts, stacks, etc. for natural or mechanical ventilation and an indoor environment, may pollute air, induce air movements in different scales or change the properties of airflow in or around them.

Building products, biological properties and activities of building occupants cause air pollution in indoor environment (Darçın, 2014b) (Table 4). Mostly, because the level of pollution and the time spent by the users in indoors are higher than those typically encountered in outdoor environment, it is two to five times higher for users to be affected adversely (Ott, 2007). In order to avoid such problems, the building indoors should be ventilated with clean air in proper conditions and polluted air should be removed via appropriate air movements. In Table 5 the formation of air movements are shown as the result of different heat gains due to the relationship of certain properties of building with sun. These properties also behave as obstacles on the path of airflow as shown in Table 6.

The contents (presence of different types of pollutants), heat and humidity level of air can be changed with different arrangements during the intake or circulation of air in building through passive or mechanical solutions (Table 7).

Appropriate clean and conditioned air can reach occupants in indoor environment in a proper speed and polluted air can be removed away if the stated properties of building are designed in a way that contribute to the formation and are compatible with movement norms of airflow (Darçın, Balanlı, 2012).

\section{A Systematic Architectural Design Approach for Accurate Air Properties in Built Environments}

Cole, et al. (2012) point out that, buildings should contribute positively to the health of human and natural systems through the way they relate to the land and engage flows. Similarly, Plaut, et al. (2012) emphasize communities' need for solutions which align human activities with natural processes through an interdependent relationship. These activities should be specific to particular place through deep understanding of regional characteristics, biological and cultural systems. Additionally, their framework LENSES' focus is highlighted for offering a perspective on how to understand place as "living". It is indicated that although a building alone may not be considered as a living organism, various elements (e.g. energy, water, air, etc.) that flow throughout a place bring life. Therefore, for a living environment, to perpetuate cycles of regeneration in all its flows, is essential.

In the light of these determinations, it is reasonable to think that to meet the clean and comfortable air requirement of occupants, the flow of proper "air" through "living" built environments by means of place specific solutions and to engage entirely to and benefit from existing aspects of the region should be primary preference. This aim can be met by using a systematic design approach which is based on patterns, relations and impacts as understanding how entities influence one another within a whole. This approach should constitute a design strategy based on systematic transfer of scientific knowledge into a built environment context. A decision making tool of this kind can also be beneficial for evaluation of architectural design quality of an existing / designed built environment in terms of air requirements. 
Table 2. Formation of air movements due to heat gains of outdoor environment components (adapted from Darçın, Balanlı, 2010)

$\begin{aligned} & \text { Natural outdoor } \\ & \text { environment } \\ & \text { components }\end{aligned}$
$\begin{aligned} & \text { Topography } \\ & \text { and sun }\end{aligned}$

Heating effects of rays increase with height and air above sun exposed higher parts rises. Air flows from cooler lower parts to higher levels during daytime and vice versa during nighttime due to rapid heat loses of high parts (Erinç, 1996).

Water and sun
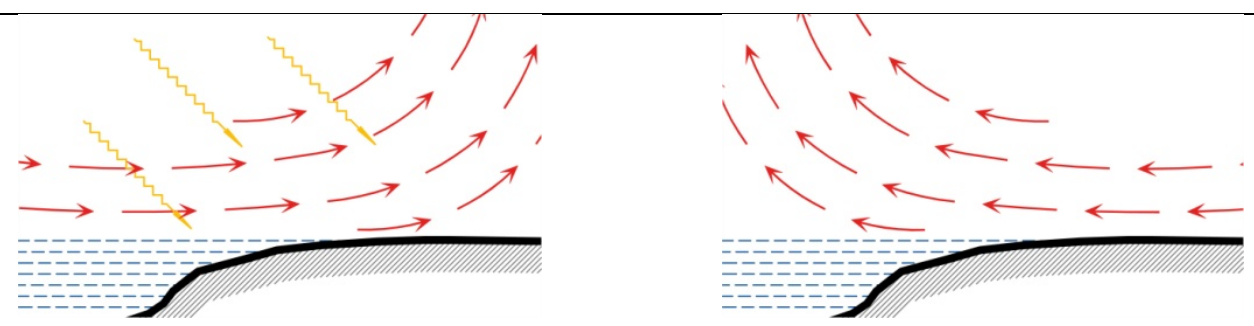

Because land surface absorbs the heat faster than surface of water, during daytime, air moves towards land, however, owing to rapid heat losses of land, a flow from land to water occurs at night (Atalay, 2005).

Green spaces and sun

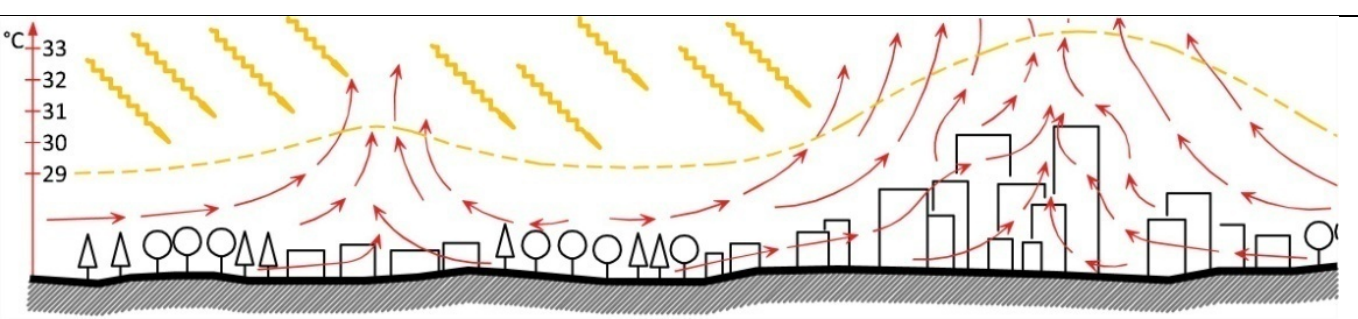

Because earth / built environment absorbs heat faster, air temperature around non-green areas is $\sim 5^{\circ} \mathrm{C}$ higher (Dimoudi, 1996). Due to this distinction, as air rises, a flow from cooler green spaces is formed.

\section{Built outdoor environment components}

Buildings / urban gaps and sun

\section{Air movements}
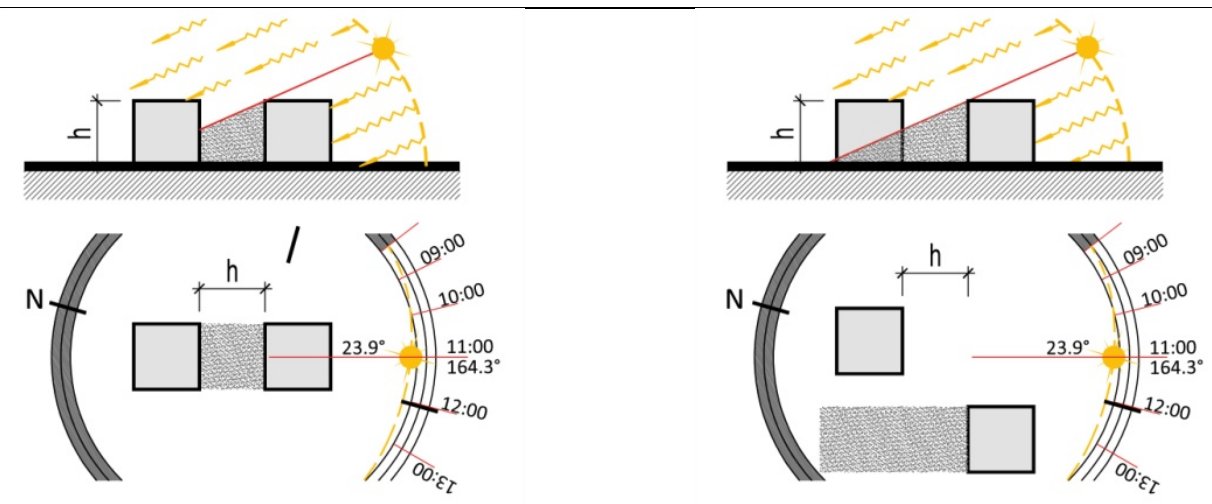

The positions of buildings of different size and form and the gaps may cause sun exposed and shadowy areas which may result in micro airflows from cooler to hotter areas. 
Table 3. Effects of outdoor environment components on properties of air movements (adapted from Darçın, Balanlı, 2010)

\begin{tabular}{ll}
\hline $\begin{array}{l}\text { Natural outdoor } \quad \text { Air movements } \\
\text { environment } \\
\text { components }\end{array}$ \\
\hline
\end{tabular}

Topography and air movements

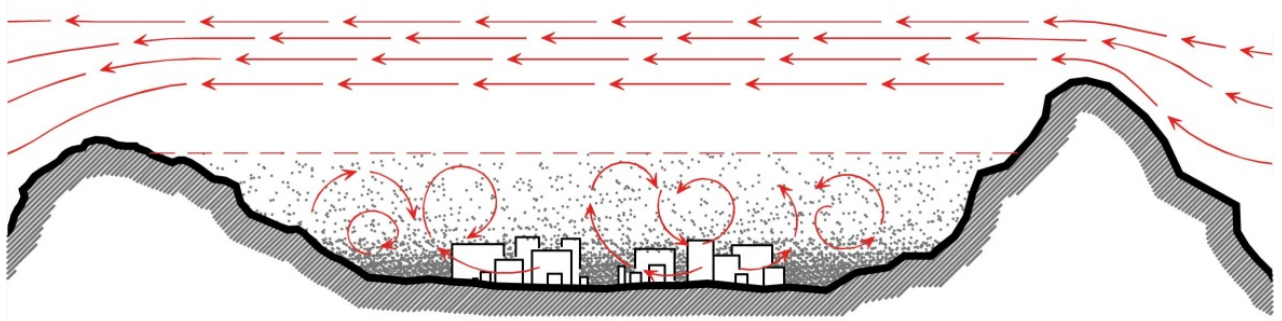

The speed, direction, behavior and form of airflow is affected by topography. Topographic features may decrease the speed and change the direction of airflow into more turbulent forms. This situation may cause accumulation of pollutants in outdoor air.

Green spaces
and air
movements
environment
components
Buildings /
urban gaps
and air
movements

The gaps positioned at a right angle with the direction of airflow may change the speed, direction, behavior and form of the flow according to the size of the gap as forming independent or group of obstacles.

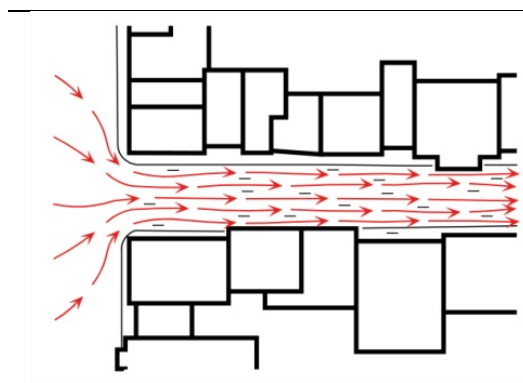

The gaps positioned at an acute angle with the direction of airflow increase the speed of the flow and cause high levels of negative pressure zones on the façades.

A proper ventilation in buildings can be managed by taking outdoor air in through the openings of the envelope, circulating it in indoor environments towards the breathing zone of occupants in proper conditions and remove the used, therefore polluted air towards outdoor environment and away from settlements (Darçın, Balanlı, 
Table 4. Main pollutant resources in Indoor environment

\begin{tabular}{|c|c|c|}
\hline \multicolumn{2}{|l|}{ Pollutant resources } & \multirow{2}{*}{$\begin{array}{l}\text { Emitted pollutants } \\
\text { VOCs (Tucker, 2001), mercury, lead (EPA, 1994), dust mites } \\
\text { (Lindwall, 2000), etc. }\end{array}$} \\
\hline Building products & $\begin{array}{l}\text { Paints, lacquers, adhesives, mastics, } \\
\text { composite wood panels, wall papers, } \\
\text { plastics, linoleum, cork plates, carpets, } \\
\text { upholsteries, furniture, lamps, etc. }\end{array}$ & \\
\hline & $\begin{array}{l}\text { Stucco, plaster, cement, concrete, stones, } \\
\text { bricks, etc. }\end{array}$ & $\begin{array}{l}\text { Radon (Balanlı, Vural, Tuna Taygun, 2004); asbestos (Balanlı, Tuna } \\
\text { Taygun, 2005), etc. }\end{array}$ \\
\hline & $\begin{array}{l}\text { Pools, sanitary systems, air conditioning } \\
\text { systems }\end{array}$ & $\begin{array}{l}\text { Virus, bacteria (CEC, 1992, Balanlı, Öztürk, 2005) PM, pollen, mold } \\
\text { spores (Ceylan, 2011), etc. }\end{array}$ \\
\hline Biological properties & Humans & $\mathrm{CO}_{2}$, VOCs (Agapiou, et al., 2013), PM, viruses and bacteria, etc. \\
\hline \multirow[t]{3}{*}{ of building occupants } & Pets and farm animals & VOCs (Ciganek, Neca, 2008), PM, etc. \\
\hline & Insects & PM and allergens (EPA, 1994) \\
\hline & Plants & CO2, pollens, PM, mold spores, etc. \\
\hline \multirow{6}{*}{$\begin{array}{l}\text { Activities of building } \\
\text { occupants }\end{array}$} & walking, running, jumping, etc. & PM \\
\hline & Combustion for heating, cooking, etc. & Smoke including PM, $\mathrm{CO}, \mathrm{SO} 2$, $\mathrm{PAHs}$, NO2, etc. \\
\hline & Using printers, copiers, etc. & $\mathrm{O}_{3^{\prime}} \mathrm{NO}, \mathrm{PM}, \mathrm{VOCs}$, etc. \\
\hline & Cleaning & PM, VOCs, etc. \\
\hline & Pest control & Pesticides \\
\hline & Repair and maintenance & Asbestos (Balanlı, Tuna Taygun, 2005), PM, mercury, lead, etc. \\
\hline
\end{tabular}

Table 5. Formation of air movements due to relationship of building properties with sun (adapted from Darçın, Balanlı, 2012)

Properties of Air movements
building

Position and orientation of building according to the sun

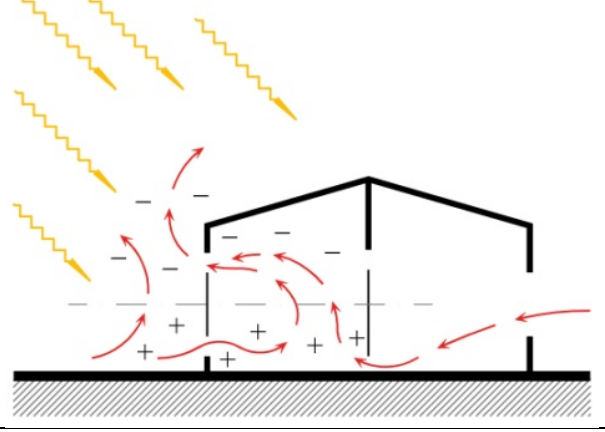

The difference in the azimuth and altitude of the sun through the day and seasons causes heat gain differences between sun exposed and shadowy areas of building envelope and interiors which can induce small scale air movements due to thermal buoyancy.
The types, positions and organization of building units and sun

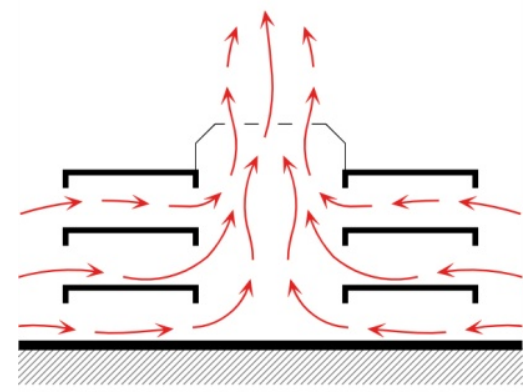

Courtyard

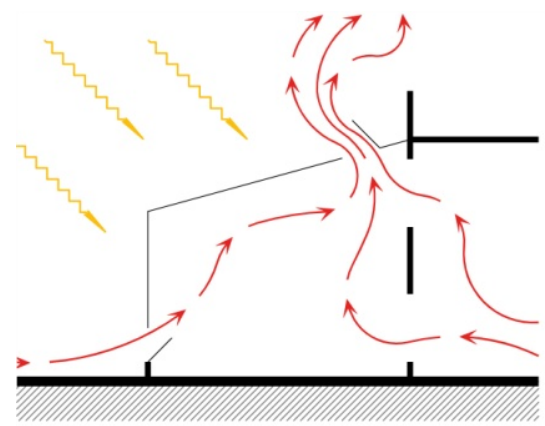

Green house

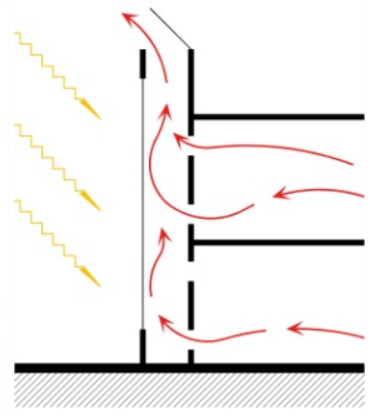

Solar chimney

The arrangement of different units and elements such as courtyards, green houses, solar chimneys, etc. can create thermal buoyancy induced air movements in / around the building.

2012). Al-Bakri (1997) and Bensalem (1991) put emphasis on, besides its function as providing clean air and driving pollutants away, ventilation is needed to assist supplying thermal comfort by cooling occupants and structure of the building and to assist acquiring the required humidity level. A procreative design phase for this kind of built 
Table 6. Effects of building on properties of air movement (adapted from Darçın, Balanlı, 2012)

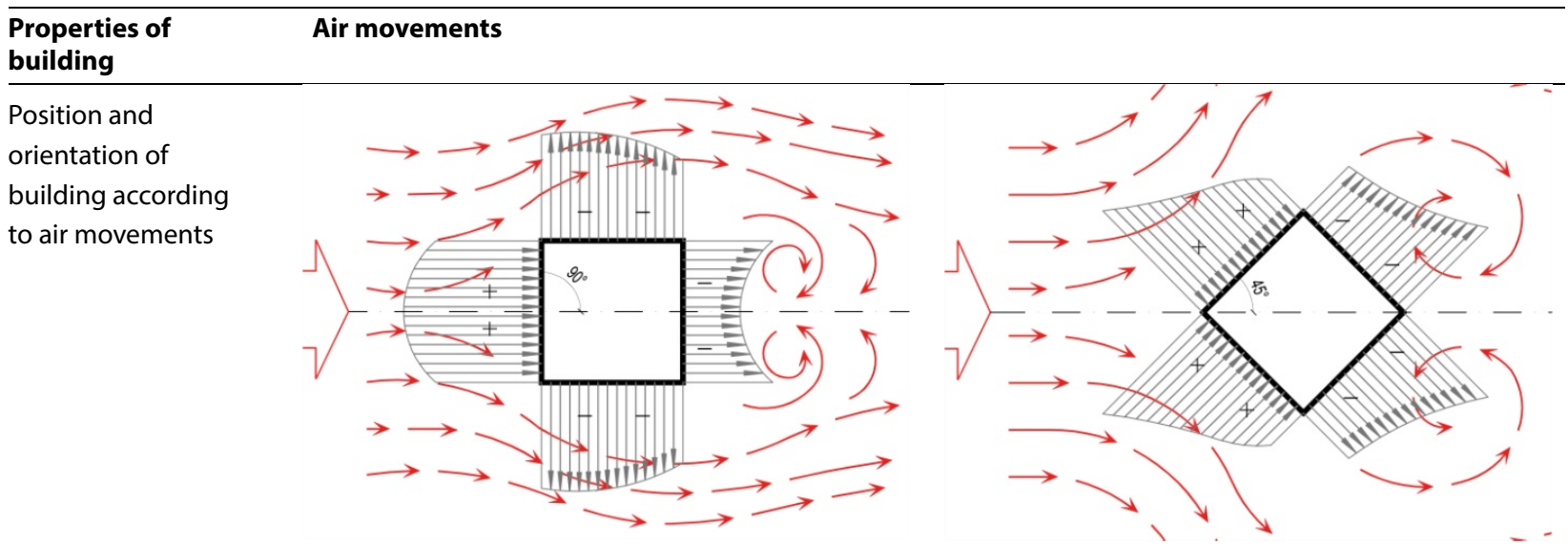

(adapted from Watson, Labs, 1993)

Different levels of pressure zones are created around a building in case of exposure to a moving air. On the windward faces, a driving force has been created due to positive and suction effect is formed in the form of turbulent movement on negative pressure zones.

Form of building and air movements
Positions and organizations of building's spaces and air movements
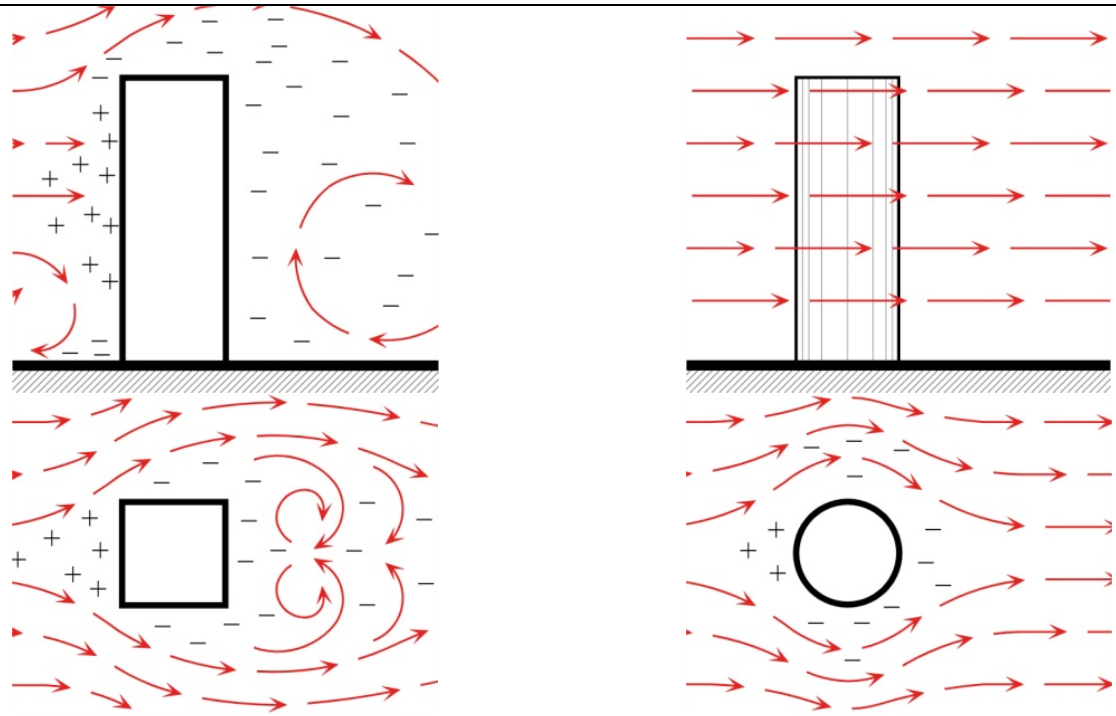

(adapted from ASHRAE, 1997)

The form of the building affects the area of envelope under different pressure zones according to the position and orientation of the building. The form of the envelope changes the speed, direction, behavior and form of airflow.
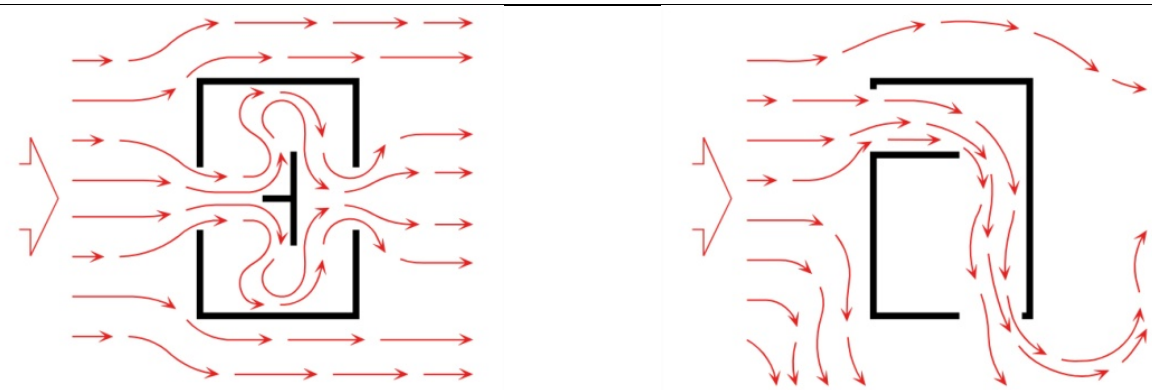

The positions and relations of indoor spaces affect the speed, direction, behavior and form of the airflow according to the properties of openings. Also air pollutants of certain spaces can be transported to others. 
Table 6. Effects of building on properties of air movement (adapted from Darçın, Balanlı, 2012) (continued)

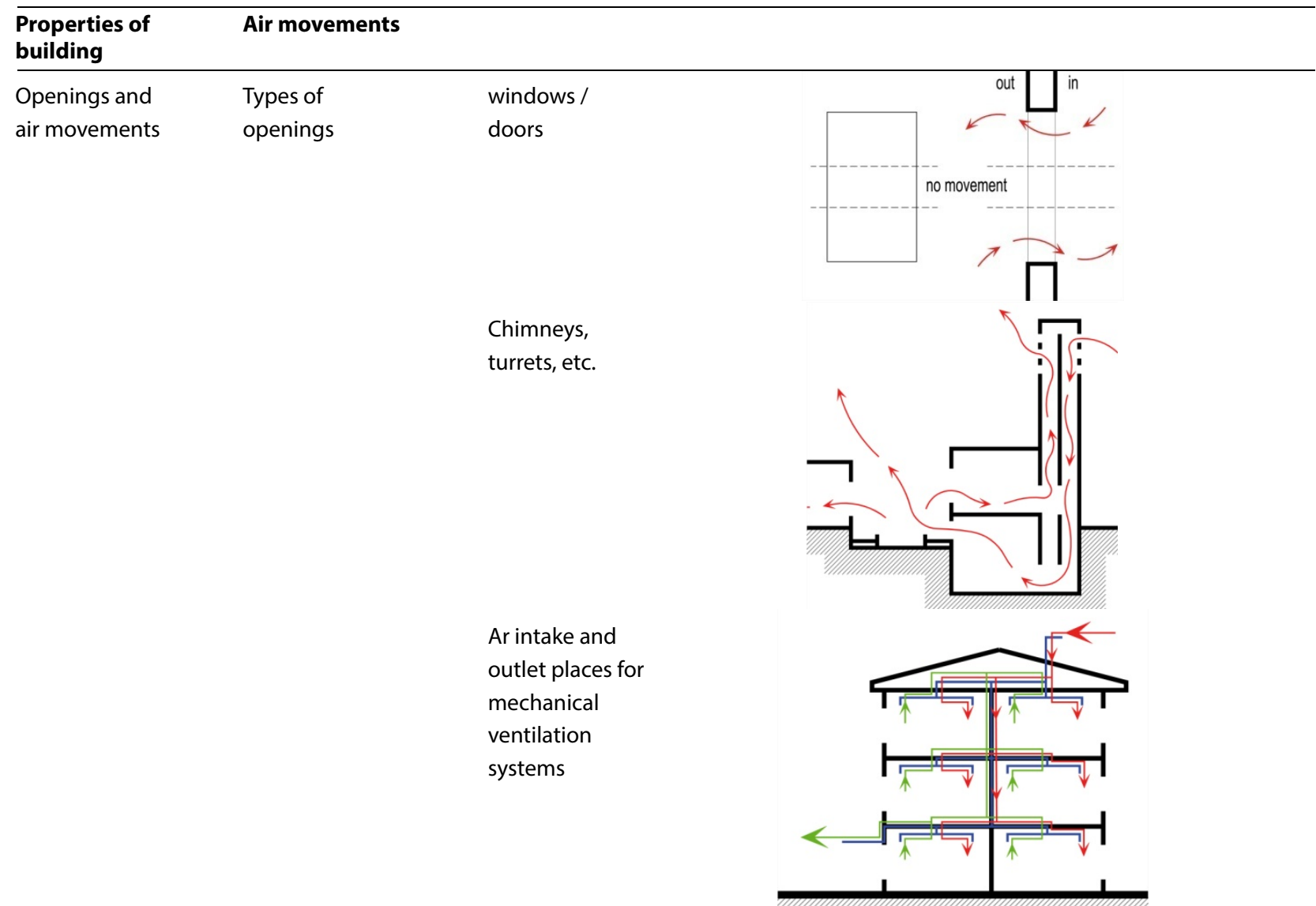

The types (form) of openings regulate the speed, behavior, direction and form of air movement according to their operations, positions and sizes.

Positions of openings
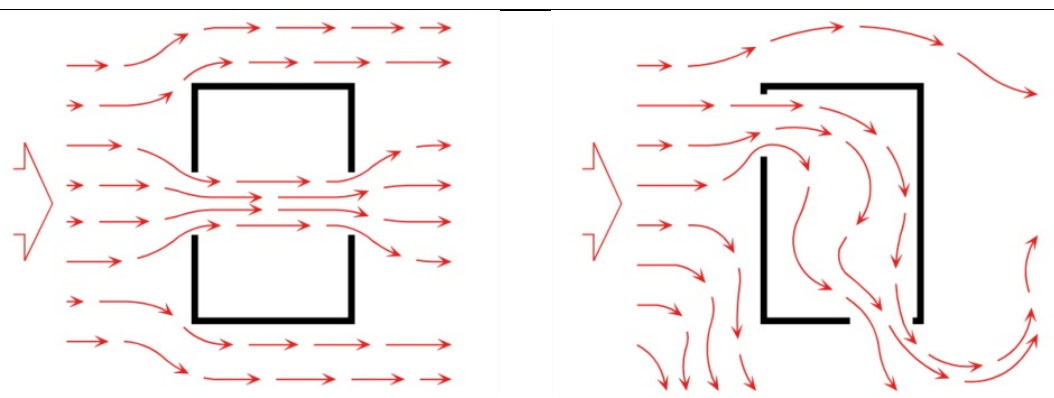

Positions of openings affect the speed, behavior, direction and form of air movements in an indoor space.

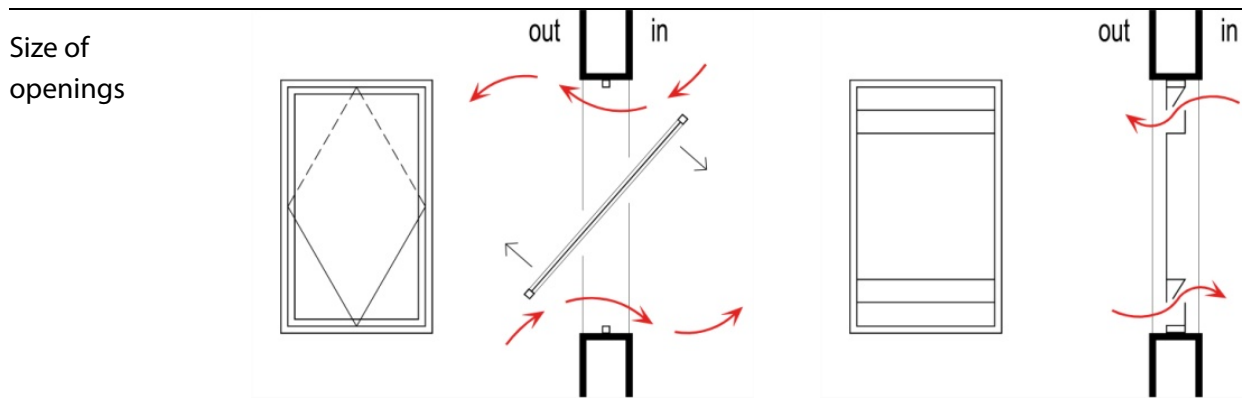

The speed, behavior, direction and form of air movements are affected by the size of openings. 
Table 7. Effects of building on properties of air quality

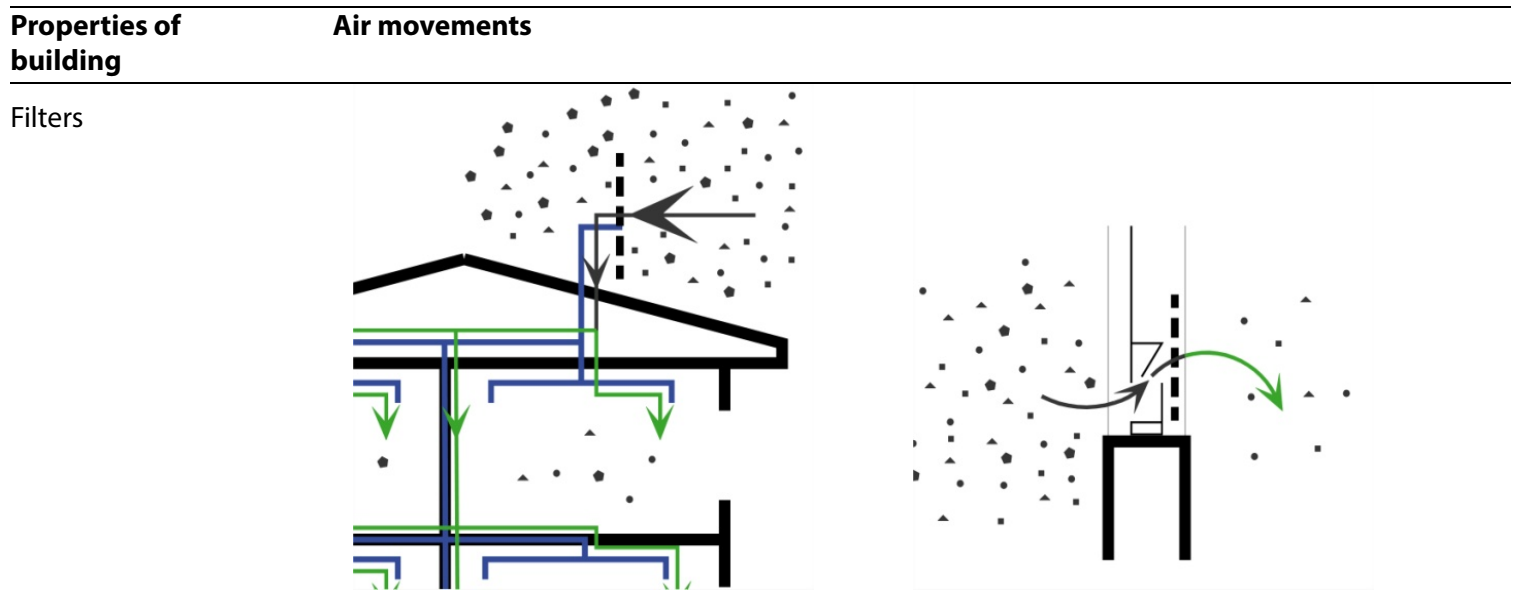

Pollutants can be filtrated during intake in mechanical systems or via passive methods.

Heating

equipment
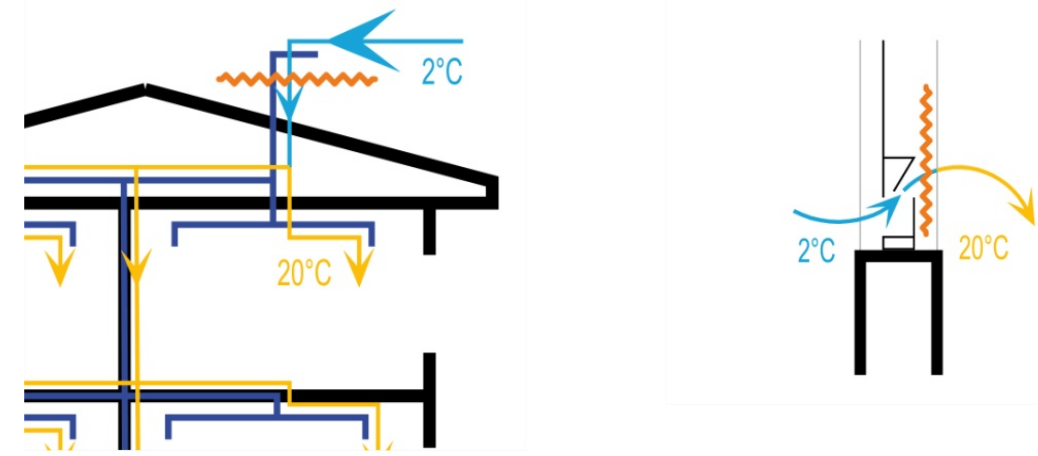

The temperature of air can be changed during intake in mechanical systems or via passive methods.

Humidifiers
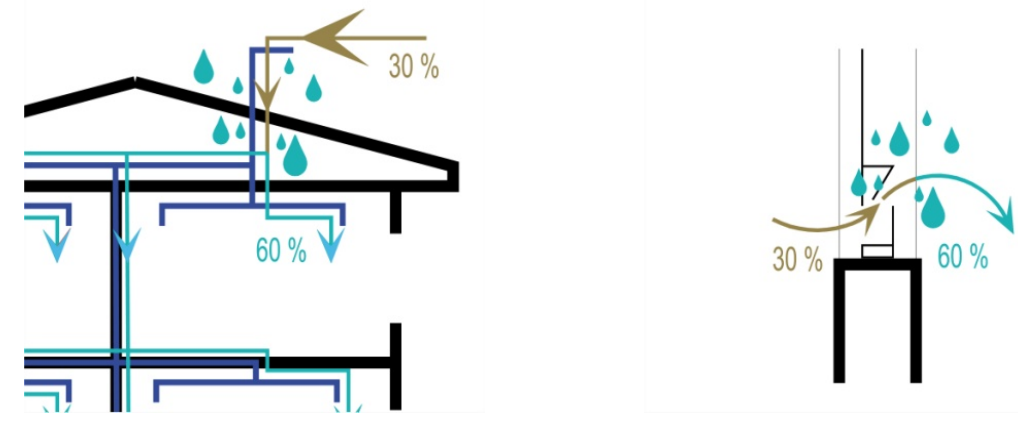

The humidity level of air can be changed during intake in mechanical systems or via passive methods.

environment can be practiced through a systematic design approach which is basically a process of successive steps including necessary analysis of the existing conditions and executing a serious of decisions in order to create the necessary physical relationship and interaction between outdoor and indoor environments.
As seen in Fig. 2, the proposed approach starts with a pre-research phase, continues with a design phase in which certain design decisions are made based upon the evaluation findings of pre-research. After that, in research (the last) phase, design is examined in terms of the quality of meeting the air related requirements and 


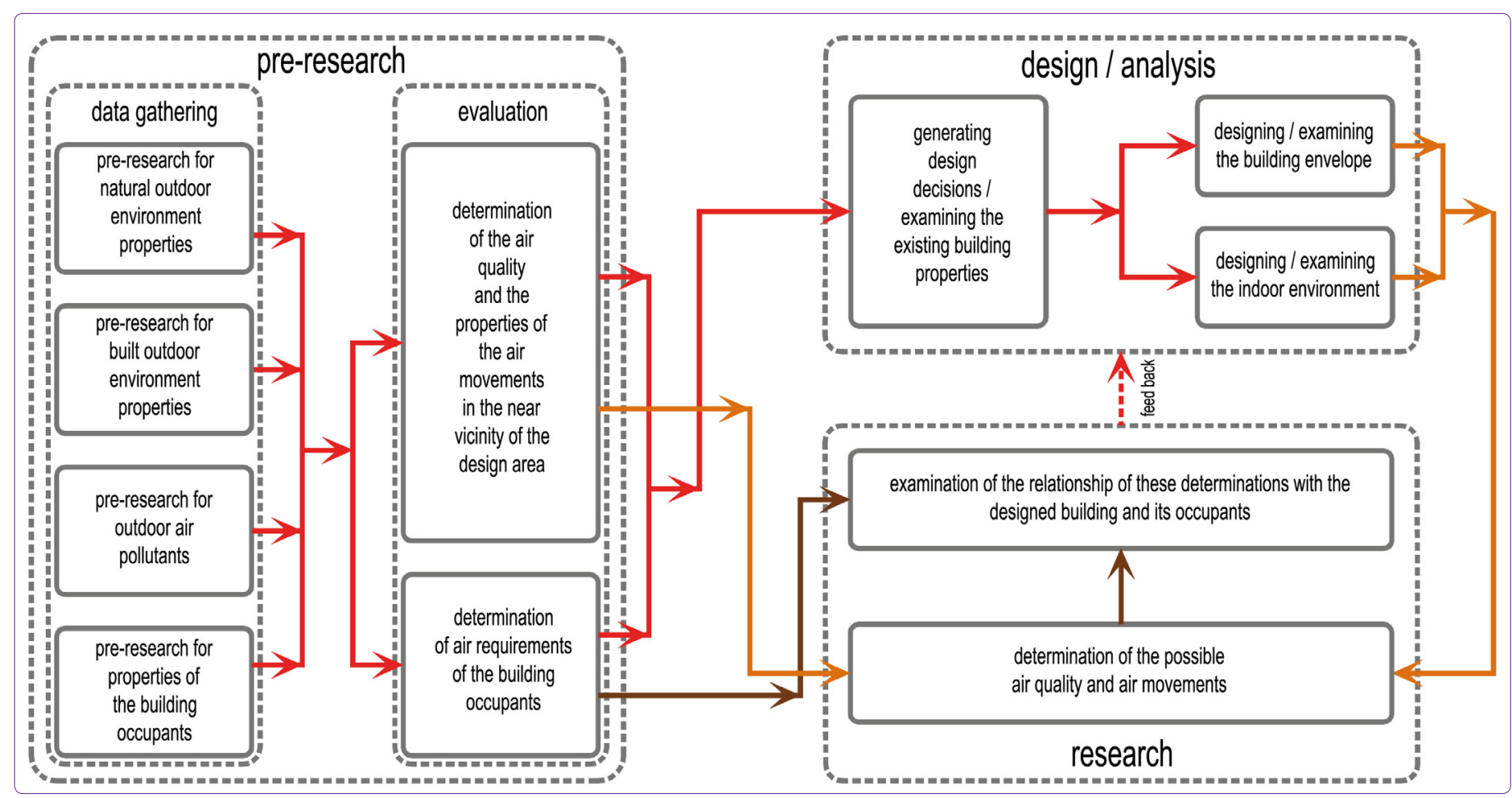

Figure 2. The main phases and relations of the proposed design approach.

if necessary, it can be revised according to the results of this examination.

\section{Pre-Research: Analysis and Evaluation of Existing Components}

In the pre-research phase of the approach, the existing environmental factors of the design area are analyzed thoroughly and it starts with collecting data about natural, built outdoor environments and biological properties of the user.

Firstly, climatic features of the natural environment: sun rays' circadian and annual altitude and azimuth, monthly average sunshine duration, monthly average prevailing wind direction and speed, monthly average air temperature, monthly average relative humidity level can be collected from meteorological surveys. Also, the altitude, roughness, slope, orientation and heat absorption features (e.g. color, density, etc.) of topography; properties (e.g. types, sizes, forms, etc.) of green spaces and wetlands in and around the design area should be determined through site observations, aerial views, base maps, previous scientific studies, etc.

Apart from natural environment, properties of existing built environment (if any) around the design area: the compactness, heights, sizes, positions, forms, orientations, heat absorption features (e.g. colors, materials, etc.) of buildings and sizes, positions, orientations, slopes, surface roughness, heat absorption features of urban gaps (e.g. roads, squares, etc.) should be gathered.
The outdoor environment should also be examined for air pollutants: the pollutant measurement data can be collected from official / scientific surveys and possible sources of pollutants can be searched in and around the design area (Table 1) via site observations, aerial views, base maps, previous researches, etc.

There is the need to determine to what extend outdoor environment must be searched. As stated in Fig. 3, the design area may be encircled with just natural outdoor environment (e.g. a sequestered building in nature like a chalet) or with both built and natural environments (e.g. a building in a settlement which is surrounded by natural environment) and to emphasize the flexibility of the focus which should be determined by the practitioner according to the components and relationships the region affords, the boundary of the outdoor environment is depicted with dashed lines.

All the collected data can be marked over site plans and sections or 3D models.

Users or user groups with similar properties can be examined according to their age, sex and other physiological properties which can be related to air requirements such as: existing or previous illnesses, body weight, etc.

These data about outdoor environment and users gathered in the first part of the pre-research phase can be evaluated by relating them under various groups. Firstly, approximate properties of air quality (temperature, humidity, pollutant types and their concentrations) in and around the design area can be predicted according 


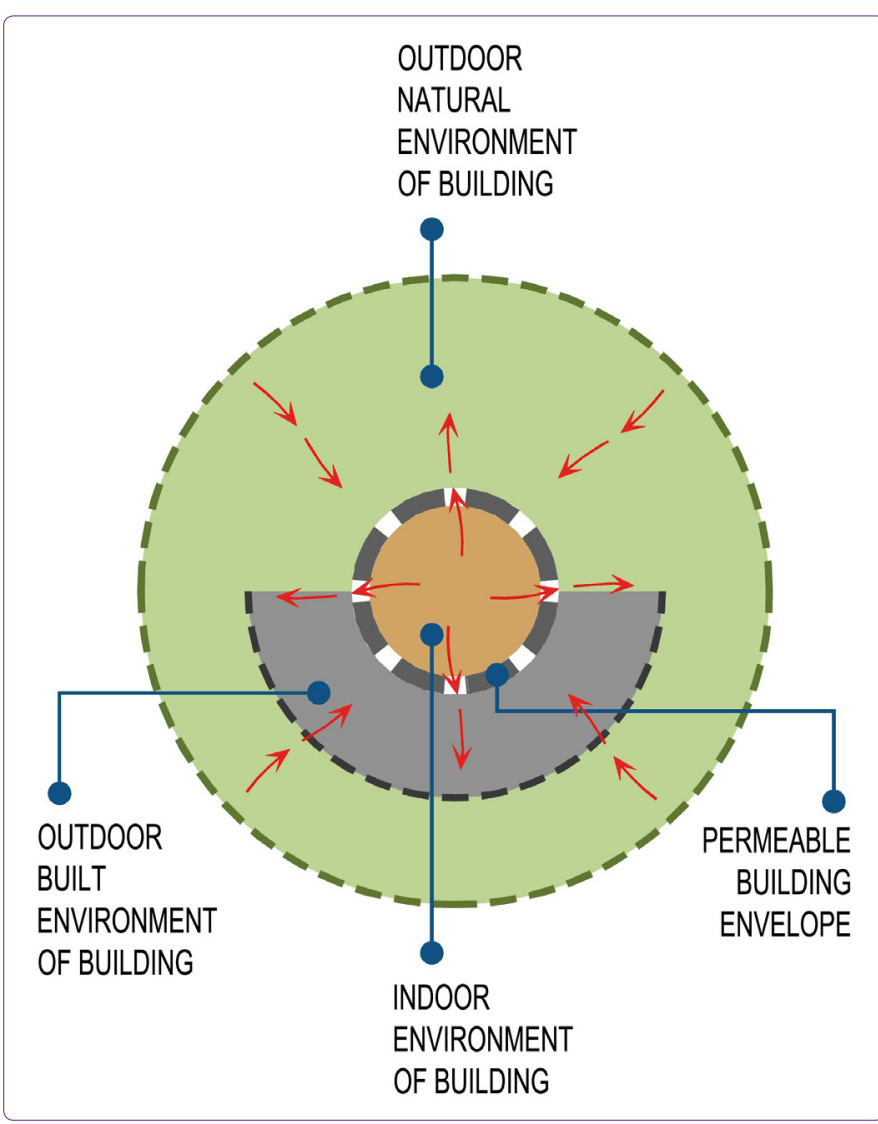

Figure 3. Outdoor and indoor environments of a building (adapted from Darçın, 2014c).

to monthly average prevailing wind direction and speed, monthly average air temperature, monthly average relative humidity, pollutant measurement data and pollutant sources. After this evaluation, by examining the relationship of sun rays with existing natural and built environment components in and around the design area: terrain's altitude, slope, orientation and heat absorption features; types, sizes, forms of green spaces, properties of wetlands, properties of buildings and urban gaps, sun exposed and shadowy areas can be specified. With this data, formation of additional airflows besides the prevailing wind in different scales in and around the design area can be estimated. As the formation of airflows are revealed, components constituting obstacles and affecting the properties of these flows: terrain's surface roughness, slope, orientation, properties of green spaces, buildings' compactness, heights, sizes, positions and orientations along with properties of urban gaps can be investigated to determine possible effects. With this study, all the determined air movements can be marked over a site plan superposed with determined pollutant sources. At the end of this evaluation, the approximate quality, temperature, humidity of air; sun exposure; the speed, direction, behavior and form of different air movements along with predicted pressure zones in near surrounding of design area can be estimated. These estimations can be visualized as airflow and air properties charts for different periods of a year over site plans, sections or 3D models.

Practitioners can predict the humidity, temperature requirements of the users and the pollutants which they are susceptible to by evaluating their biological data and consulting scientific studies and standards.

In Fig. 4 the relationship of data for this evaluation in pre-research phase is shown in detail.

Design / Analysis of Building in terms of Air Properties

In this phase of the approach, practitioners can produce a serious of decisions for the design of building in terms of air related features. These decisions should be based upon the findings of pre-research phase.

Primarily, the type of ventilation and its approximate usage periods should be decided. According to the pollution, humidity and temperature of outdoor air and estimated requirements of the user, the need for filtration of pollutants and / or conditioning of air can be determined for certain periods of time along a year. After these determinations, practitioners should decide how to execute these organizations; whether natural / passive methods will be sufficient, is there a need for mechanical systems or will it be reasonable to use both in turns for different periods.

For either choice of ventilation methods, practitioners should decide the proper areas for air intake points based on the estimated properties of air, airflows and pressure zones.

As the design phase of the building continues with the decisions about the form, size, position, orientation, products of building envelope; type, form, size, position of openings and type, position, interior organization, size, interrelation, products of building units along with proper places of users' activities, practitioners can designate the proper ways of circulating the air in indoors and suitable areas to outlet the used air by checking the determined properties of air around the design area so that polluted air can be transported away from building and other built environments. The products of the building should not emit pollutants and the proper places for users' activities in building units should be decided in coordination with air circulation path: pollutants produced by the users and their activities (Table 4) should not affect other building units / users.

This approach can also be used as an examination tool for assessment of an existing building in terms of air and ventilation adequacy. For this examination, the listed properties of existing building's ventilation, envelope and units should be collected and inscribed as plans, sections, elevations or 3D models in this step. 


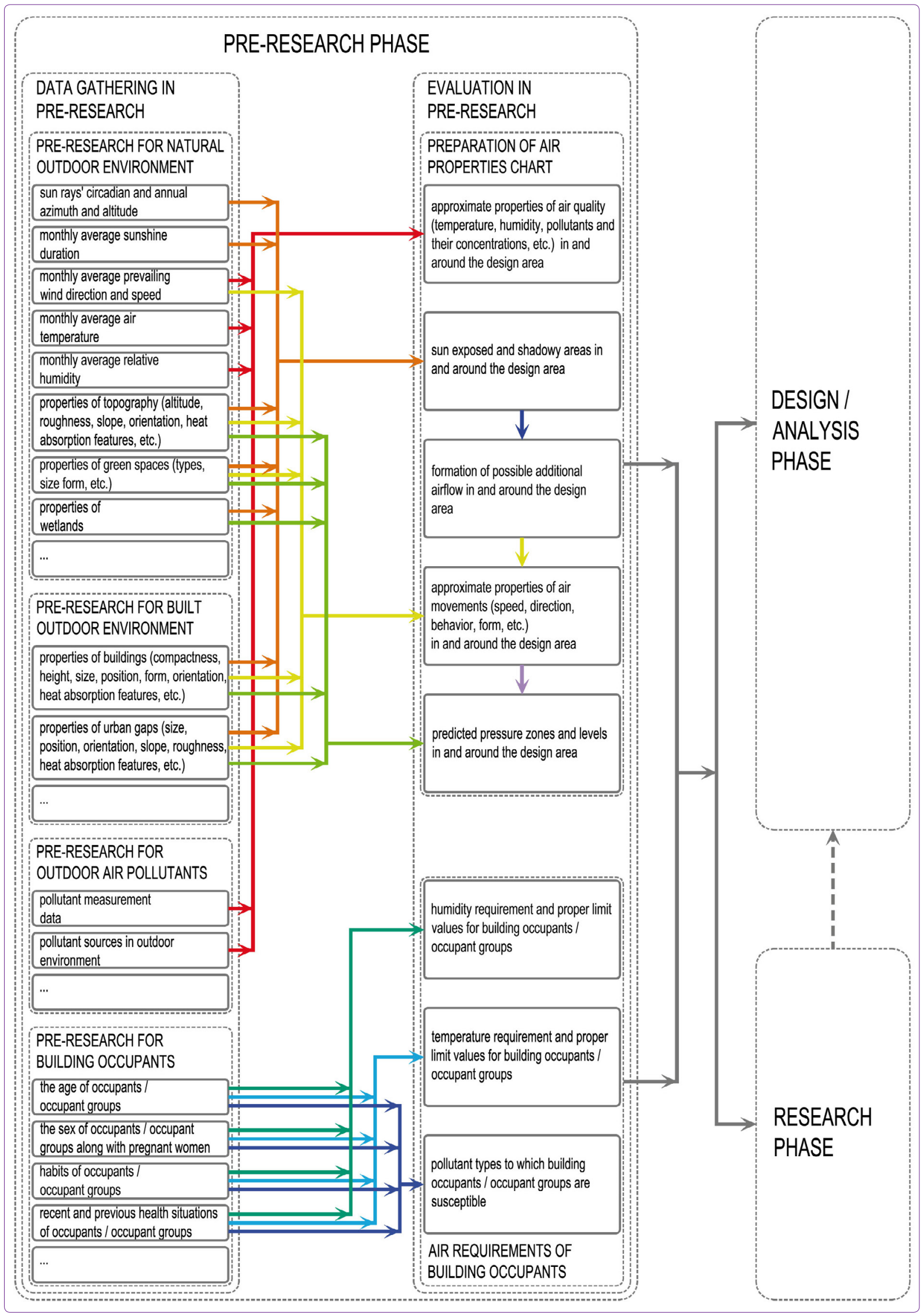

Figure 4. Pre-research phase. 


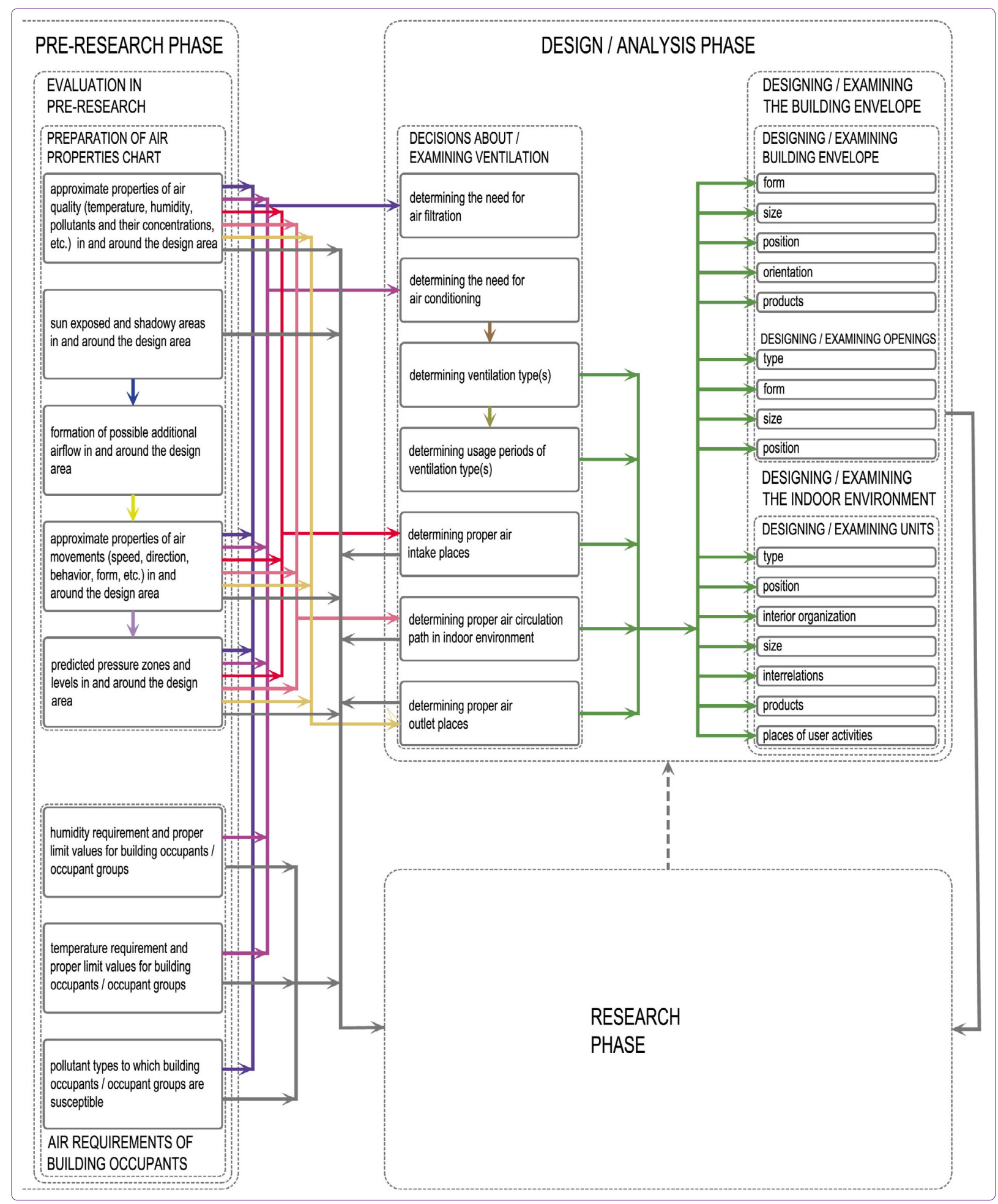

Figure 5. Design / analysis phase.

In Fig. 5 the relationship of data for design / analysis phase is shown in detail.

Research: Evaluation of Building according to Its Air and Ventilation Efficiency

Once the design of the building is finalized / the required properties of the building are gathered, the estimated quality of air, the formation and properties of air movements in and out of the building should be analyzed and evaluated in this last phase of the approach.

Firstly, the formation of additional airflows besides the flows around the design area predicted at the end of the pre-research phase can be estimated by examining the 


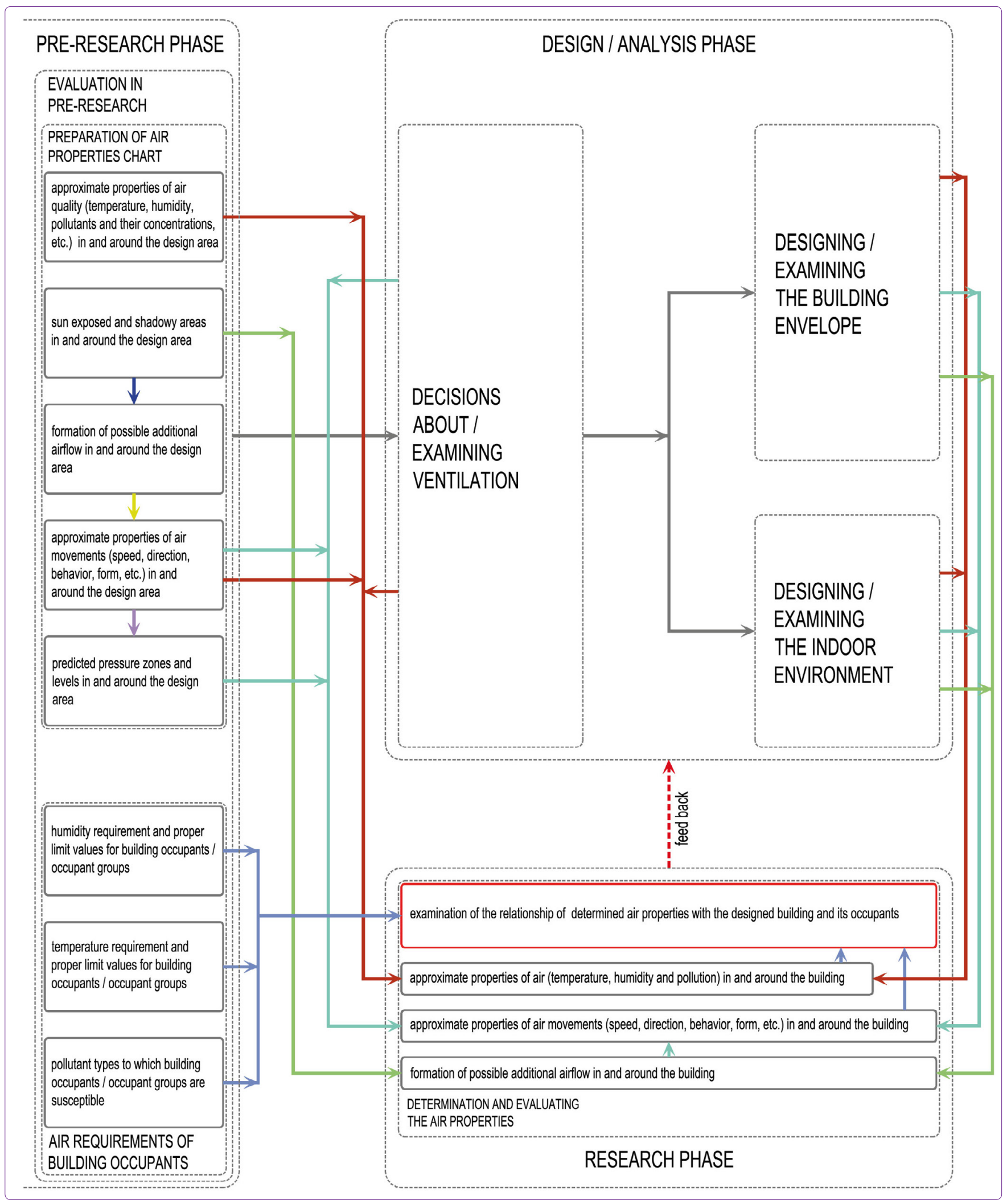

Figure 6. Research phase.

relationship of sun exposure of the design area with the envelope and units of the building in order to display different levels of pressure zones and possible additional flows.
As all the possible airflow formations are determined, the properties of building envelope and units can be examined according to their effects over the properties of the airflow 


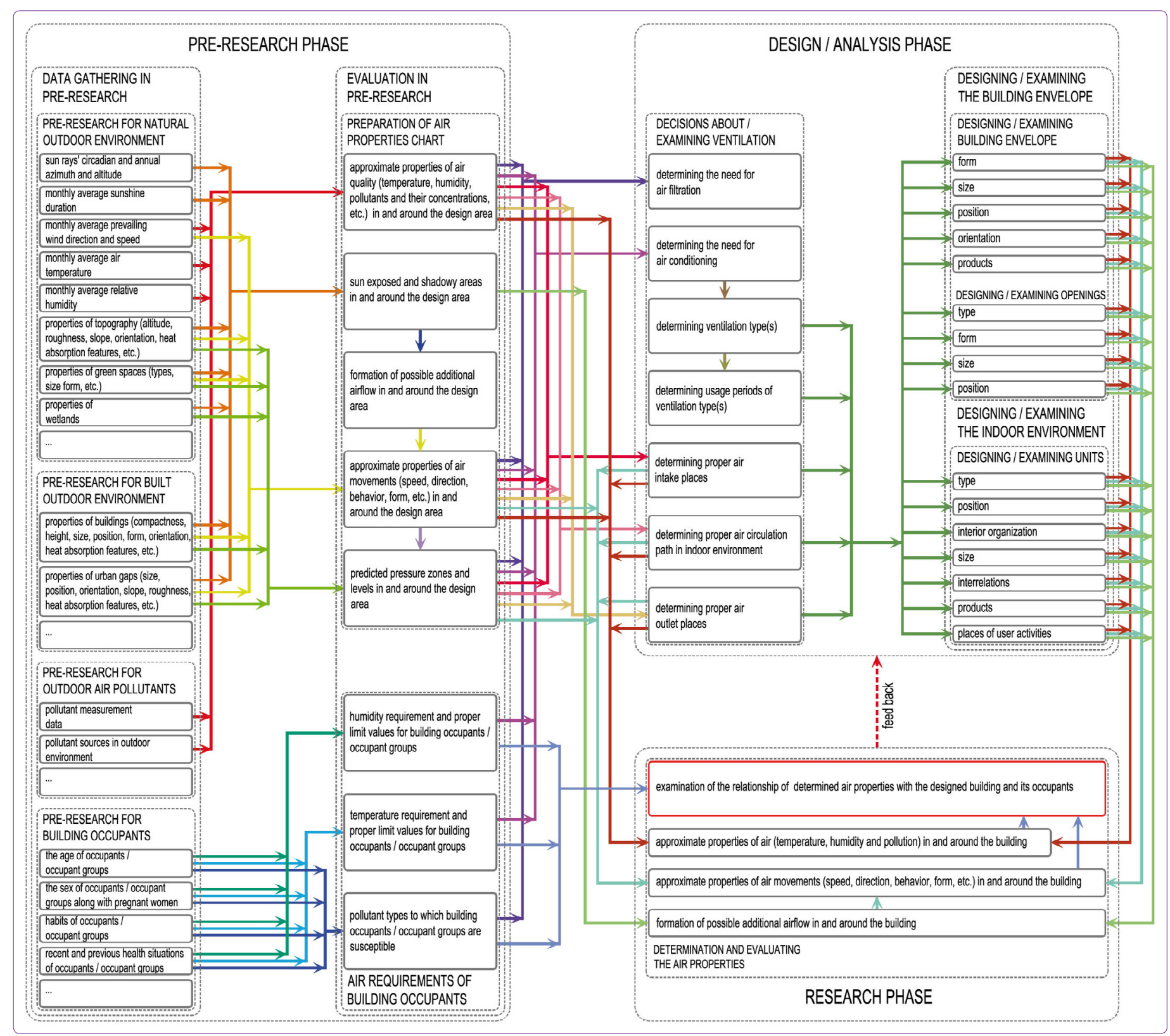

Figure 7. Architectural design approach for accurate air properties in built environments.

in and out of the building. The possible direction, speed, behavior and form of the air movements can be visualized as airflow charts over plans, sections or 3D models. At this point, if needed, air temperature, humidity and flow rate can be measured or modeled according the collected data, after deciding proper measurement points / modeling techniques and other details such as measurement time, duration, equipment, etc.

The potential air pollutant sources in the indoor environment: the building products, users and their activities can also be marked over the same plans, sections or 3D models; thereby the transportation of pollutants in indoor environment and possible adverse exposures can be estimated on the airflow charts.
In order to evaluate the properties related to air in the building, practitioners should examine airflow charts and investigate whether pollutant free air at required temperature, humidity and speed can be circulated through the breathing zones of users in every space without consuming non-renewable energy sources and polluting the environment. According to the findings of this investigation, necessary alterations and changes can be done in design / organization of the building properties by feedbacks.

In Fig. 6 the relationship of data for research phase and in Fig. 7 the whole approach is shown in detail.

\section{Conclusion}

To create an indoor environment which fulfills its users' 
air related requirements effectively, the outdoor and indoor environments of the building and its envelope should be designed consciously. This design phase with accurate decisions which will affect the air properties positively can be completed by using a framework that offers a strategic guidance and support to practitioners. By shifting the current focus from individual building performance to underlying patterns and relations between different spatial scales that affect the air and its properties, a systematic architectural design process approach has been developed including three main phases of successive steps of analysis, evaluation and decision making. With the first phase: a detailed pre-research in which many environmental factors related to air and its properties are collected and related to each other to create tangible determinations about the design area and its surrounding which provides a deep understanding of regional and user characteristics. The approach guides designers to create a serious of design decisions which are based upon these determinations in the second phase. Because of this interdependence, a re-established relationship between natural and human systems through built environment can be formed. In the third and last phase, the approach gives an opportunity to evaluate the design and supply feedbacks if needed. Thereby a built environment which is compatible to its bigger and smaller systems, linked to each other through impacts and effects, can be designed, constructed and used.

It is believed that designing this kind of built environment can conscientiously integrate humans and natural systems and may have some net positive beneficial, supportive results not only for air and ventilation, but also for other living / non-living entities and humans contributing to their healthy and partnered existence.

The proposed design / evaluation approach constitutes a general framework with details available to change and improve. In further researches, using this approach is believed to bear importance and will be beneficial in order to organize different components through place specific patterns in regard to their effects on each other and on the approach's overall quality, to find appropriate and procreative ventilation solutions originated from and convenient to possibilities the site offers.

\section{References}

Agapiou, A., Mochalski, P., Schmid, A., Amann, A, (2013) "Potential Applications of Volatile Organic Compounds in Safety and Security", Volatile Biomarkers Non-Invasive Diagnosis in Physiology and Medicine, First Edition, Chapter 24: 515-558, Amsterdam: Elsevier.

Al-Bakri, U. A. R. (1997) Natural Ventilation in Traditional Courtyard Houses in the Central Region of Saudi Arabia, Unpublished doctoral dissertation, Welsh School of Architecture,
University of Wales, Cardiff.

ASHRAE Fundamentals, (1997) Binalar Etrafinda Hava Akışı (Airflow Around Buildings), Tesisat Mühendisleri Derneği, Yayın No: 2.

Atalay, ì. (2005) Genel Fizikî Coğrafya (General Physical Geography), İzmir: Meta Basım Yayın.

Bensalem, R. (1991) Wind-Driven Natural Ventilation in Courtyard and Atrium-Type Buildings, Unpublished doctoral dissertation, School of Architectural Studies, University of Sheffield, Sheffield.

Bérubé, K. A., Richards, R. J. (2000) Physicochemical Identification and Comparative Biopersistence of Indoor and Outdoor Airborne Particulate Matter, Joint Research Programmes on Outdoor and Indoor Air Pollution (Review of Progress 1999), 37-39, Leicester: MRC Institute for Environment and Health.

Balanlı, A. (2011) "Building Biology and Examination Models for Buildings", Sick Building Syndrome in Public Buildings and Workplaces, Chapter 7: 113-134, Heidelberg: Springer.

Balanlı A.,Tuna Taygun, G. (2005) "Yapı Biyolojisi ve Asbest" (Building Biology and Asbestos), Mimar.İst, 16, 107-110.

Balanlı, A., Öztürk, A. (1995) "Yapının İç ve Dış Çevresinin Yapı Biyolojisi Açısından İrdelenmesi" (Examination of Indoor and Outdoor Environment of the Building in terms of Building Biology), Sağlıklı Kentler ve İnşaat Mühendisliği Sempozyumu, 45-55, İzmir.

Balanlı, A., Öztürk, A. (2005) “Lejyonellosis'in Yapı Biyolojisi Açısından İrdelenmesi" (Examination of Legionellosis in terms of Building Biology), Mimarlık Dekorasyon Dergisi, 138, 20-22.

Balanlı, A., Vural, S. M., Tuna Taygun, G. (2004) "Yapı Ürünlerindeki Radonun Yapı Biyolojisi Açısından İrdelenmesi" (Examination of Radon in Building Products in terms of Building Biology), 2. Ulusal Yapı Malzemesi Kongresi ve Sergisi, 378386, İstanbul.

CEC, (1991). Effects of Indoor Air Pollution on Human Health Indoor Air Quality \& Its Impact on Man, Environment and Quality of Life, (Report No: 10 EUR14086EN). Luxembourg: European Concerted Action.

CEC, (1992). Guidelines for Ventilation Requirements in Buildings, European Collaborative Action Indoor Air Quality \& Its Impact on Man, (Report No: 11 EUR14449EN), Luxembourg.

Ceylan, A. (2011) "iklimlendirme Sistemlerinin Yapı İçi Hava Niteliği Üzerindeki Olumsuz Etkileri" (The Negative Effects of Air Conditioning Systems on Indoor Air Quality), Unpublished master's thesis, YTÜ FBE, İstanbul.

Ciganek, M., Neca, J. (2008) "Chemical Characterization of Volatile Organic Compounds on Animal Farms", Veterinarni Medicina, 53(12), 461-651.

Cole, R. J. (2012) "Regenerative Design and Development: Current Theory and Practice", Building Research \& Information, 40(1), 1-6.

Cole, R. J., Busby, P., Guenther, R., et al. (2012) "A Regenerative Design Framework: Setting New Aspirations and Initiating New Discussions", Building Research \& Information, 40(1), 95-111.

Darçın, P. (2014a) “Çevreci Yapma Çevre Kavramının Evrimi: Yenileyici (Rejeneratif) Tasarım Yaklaşımı" (The Evolution of EcoFriendly Built Environment Concept: Regenerative Design Approach), Mimar.İst, 51, $50-56$. 
Darçın, P. (2014b) "Yapı İçi Hava Kirliliğinin Değerlendirilmesine Yönelik Bir Yaklaşım" (An Approach for the Assessment of Indoor Air Pollution), Unpublished doctoral dissertation, YTÜ, FBE, İstanbul.

Darçın, P. (2014c) "Yenileyici (Rejeneratif) Tasarım Kapsamında Doğal Havalandırmaya Yönelik Bir Yaklaşım" (An Approach for Natural Ventilation in terms of Regenerative Design), Mimarlık, 379, $69-72$.

Darçın, P., Balanlı, A. (2010) “An Examination of Building Ventilation Methods in Terms of Environment and Natural Ventilation", Ecological Agenda International Conference on New Perspectives in Eco-Technologies and Eco-Economy, 118-131, İstanbul.

Darçın, P., Balanlı, A. (2012) "Yapılarda Doğal Havalandırmanın Sağlanmasına Yönelik IIlkeler" (Natural Ventilation Principles in Buildings), Tesisat Mühendisliği Dergisi, 128, $33-42$.

Darçın, P., Tuna Taygun, G., Vural, S. M. (2016) “Evaluation of LEED 'Water Efficiency' Case Study: Diyarbakır Turkey”, 11th Conference on Sustainable Development of Energy, Water and Environment Systems, Lisbon.

Dimoudi, A. (1996) "Microclimate", Passive Cooling of Buildings, London: James \& James Science Publishers.

du Plessis, C. (2012). "Towards a Regenerative Paradigm for the Built Environment", Building Research \& Information, 40(1), 7-22.

EEA, (2013) Air Quality in Europe - 2013 (Report, No: 9-2013), Copenhagen: European Environment Agency,

EPA, (1994) Indoor Air Pollution An Introduction for Health Professionals, (EPA 402-R-94-007), American Lung Association, Environmental Protection Agency, Consumer Product Safety Commission, American Medical Association.

EPA, (2001) Mold Remediation in Schools and Commercial Buildings, (EPA 402-K-01-001), Washington DC: Office of Air and Radiation Indoor Environments Division.

Erinç, S. (1996) Klimatoloji ve Metotları (Climatology and its Methods), İstanbul: Alfa Basım Yayın.

Flachsbart, P. G. (2007) "Exposure to Carbon Monoxide", Exposure Analysis, Chapter 6, 113-146, Boca Raton: CRC Press Taylor \& Francis Group.

Haggard, B., Reed, B., Mang, P. (2008) "Regenerative Development", Revitalization, March/April: 24-26.

Jantunen, M. (2000) "Health Risk of Indoor Air Fine Particulate Matter", Indoor Environment and Human Exposure, Risk Assessment in Relation to Indoor Air Quality, European Collaborative Action on Urban Air, (Report No: 22, EUR 19529
EN), Luxembourg: Office for Official Publications of the European Communities.

Lindwall, T. (2000) "Allergy to House Dust Mites", Risk Assessment in Relation to Indoor Air Quality, European Collaborative Action on Urban Air, Indoor Environment and Human Exposure, (Report No: 22, EUR 19529 EN), Luxembourg: Office for Official Publications of the European Communities.

Muilenberg, M. L. (2001) "Indoor Pollutants: Pollen in Indoor Air: Sources, Exposures and Health Effects", Indoor Air Quality Handbook, Chapter 44, New York: McGraw-Hill.

Ott, W. R. (2007) "Exposure Analysis: A Receptor - Oriented Science", Exposure Analysis, Chapter 1: 3-33, Boca Raton: CRC Press Taylor \& Francis Group.

Pedersen Zari, M. (2012) "Ecosystem Services Analysis for the Design of Regenerative Built Environments", Building Research \& Information, 40(1), 54-64.

Plaut, J. M., Dunbar, B., Wackerman, A., et al. (2012) "Regenerative Design: The LENSES Framework for Buildings and Communities", Building Research \& Information, 40(1), 112-122.

Rees, W. E. (1999) "The Built Environment and the Ecosphere: A Global Perspective", Building Research \& Information, 27, 206-220.

Rees, W. E. (2008) "Human Nature, Eco-Footprints and Environmental Injustice", Local Environment The International Journal of Justice and Sustainability, 13(8), 685-701.

Spellman, F. R. (2009) "All About Air", The Science of Air Concepts and Applications, Second Edition, Chapter 2: 15 - 30, Boca Raton: CRC Press Taylor \& Francis Group.

Tucker, W. G. (2001) "Volatile Organic Compounds", Indoor Air Quality Handbook, Chapter 31, New York: McGraw-Hill.

Wallace, L. A., Gordon, S. M. (2007) "Exposure to Volatile Organic Compounds", Exposure Analysis, Chapter 7:, 147-179, Boca Raton: CRC Press Taylor \& Francis Group.

Watson, D., Labs, K. (1993) Climatic Building Design: Energy Efficient Building Principles and Practices, New York: McGraw Hill.

Yaşa, E. (2004) “Avlulu Binalarda Doğal Havalandırma ve Soğutma Açısından Rüzgâr Etkisi ile Oluşacak Hava Akımlarına Yüzey Açıklıklarının Etkisinin Deneysel İncelenmesi" (A Wind Tunnel Investigation of the Effects of the Surface's Apertures on Wind Velocity and Air-Flow in the Courtyards from the Point of View of the Natural Ventilation and Passive Cooling), Unpublished master's thesis, İstanbul Teknik Üniversitesi, Fen Bilimleri Enstitüsü, İstanbul. 